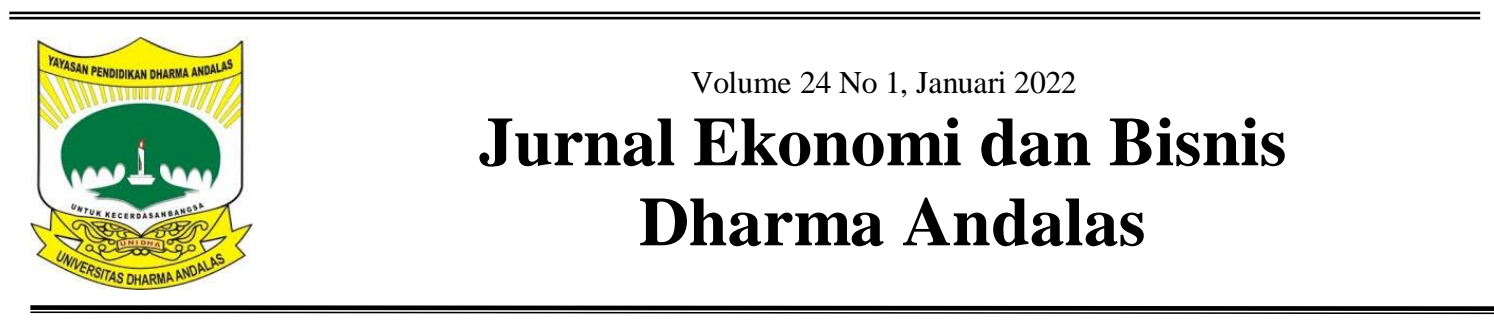

\title{
The Effect Of Special Allocation Funds, Profit Sharing Funds And Rest Of Budget Calculations On Capital Expenditures In District And City Governments In West Sumatra Province
}

\author{
Febryandhie Ananda ${ }^{1}$, Dewi Hariani ${ }^{2}$ \\ Sekolah Tinggi Ilmu Ekonomi KBP ${ }^{1,2}$ \\ e-mail:febryandhie@akbpstie.ac.id ${ }^{1}$ \\ dewiharianiamendra@gmail.com ${ }^{2}$
}

\begin{abstract}
The purpose of the study was to determine the effect of special allocation funds, profit-sharing funds and the remainder of the budget calculation on capital expenditures (study on Regency and City Governments in West Sumatra Province). This type of research is quantitative research. The scale used is the ratio measurement scale. The data used is time series data analysis. Source of data in the form of secondary data. The population is 19 regencies and cities in West Sumatra Province, which consists of 12 regencies and 7 cities for the 2014-2019 period. The sampling technique used was saturated sampling. Data collection technique is documentation. The data analysis technique is multiple linear regression analysis. Based on the results of the research that has been done, it can be concluded that the DAK has a significant positive effect on capital expenditures so that the hypothesis is accepted. DBH has a significant positive effect on capital expenditure so that the hypothesis is accepted. SILPA has no significant effect on capital expenditure so that hypothesis is rejected. DAK, DBH and SILPA together have a significant positive effect on capital expenditures. The adjusted $R$ square value is 0.668 , this means $66.8 \%$ of capital expenditure in 19 regencies and cities in West Sumatra Province which can be explained by special allocation funds (DAK), profit sharing funds (DBH) and excess budget calculations (SILPA). ) while the remaining $33.2 \%$ is explained by other factors not examined in this study.
\end{abstract}

Keywords:

Special Allocation Fund, Revenue Sharing Fund, Budget Calculation Over, Capital Expenditure

\section{INTRODUCTION}

The provinces or districts and cities in Indonesia that are the main factor in preparing their financial estimates are the budget. The budget is the main thing that determines what we are more often familiar with as the regional income and expenditure budget or more commonly known among our people as the APBD. In order to explore the potential that exists in the regions, the central government gives the broadest right to use its own budget (financial sources), where here the regions have implications for the authority given to them to manage and develop their respective regions (Mentayani \& Rusmanto, 2013).

The authority for local governments that is obtained from the central government is referred to as the regional autonomy policy. Regional autonomy is enforced with the aim of 
accelerating economic growth and regional development, it is also useful for reducing the gaps that occur between communities and improving and improving the quality of public services to become more efficient (Muhammad Syukri \& Hinaya, 2019). Regional autonomy provides opportunities for local governments to further develop regional potential.

The development of the potential for regional expenditure is carried out by meeting the needs of regional expenditures whose planning is carried out through the regional revenue budget (APBD), one of the components of which is capital expenditure. Capital expenditures describe budget expenditures used to acquire tangible assets and other assets, with benefits provided for more than one accounting period and also exceeding the lowest limit for the determination of fixed assets or other assets by the government (Minister of Finance Regulation (PMK) Number 91/PMK .06/2007).

according to Halim (2014) capital expenditures are included in regional expenditures used for the purchase and provision of tangible goods whose benefits are more than a year, which are used to build infrastructure and provide public facilities. according to Aditya \& Maryono (2018) The grouping of capital

Table 1

The Value of Capital Expenditures in Regency and City Governments West Sumatra Province Fiscal Year 2014 -2019 (Thousand Rupiah)

\begin{tabular}{|c|c|c|c|c|c|c|}
\hline \multirow{2}{*}{ District / City } & \multicolumn{6}{|c|}{ Capital Expenditure } \\
\hline & 2014 & 2015 & 2016 & 2017 & 2018 & 2019 \\
\hline \multicolumn{7}{|l|}{ DISTRICT } \\
\hline Regency Agam & $153.139 .990,00$ & $161.073 .310,92$ & $192.813 .122,00$ & $270.015 .747,00$ & $229.920 .478,00$ & $288.083 .137,00$ \\
\hline Regency. Dharmasraya & $183.618 .751,74$ & $264.546 .590,31$ & $265.428 .155,99$ & $270.434 .562,31$ & $241.664 .354,41$ & $246.373 .488,44$ \\
\hline $\begin{array}{l}\text { Regency. Mentawai } \\
\text { Islands }\end{array}$ & $175.647 .660,62$ & $251.482 .269,52$ & $277.846 .773,62$ & $313.680 .549,81$ & $343.359 .974,12$ & $421.946 .874,42$ \\
\hline Regency Lima Puluh Kota & $191.360 .605,00$ & $174.180 .411,29$ & $252.966 .503,00$ & $233.117 .427,00$ & $254.780 .324,00$ & $275.666 .023,00$ \\
\hline Regency Padang Pariaman & $202.289 .753,66$ & $210.056 .212,00$ & $306.540 .211,37$ & $367.120 .206,95$ & $305.425 .405,90$ & $357.048 .704,47$ \\
\hline Regency Pasaman & $157.967 .854,42$ & $176.591 .156,39$ & $234.016 .497,15$ & $184.936 .891,01$ & $138.329 .076,09$ & $165.096 .902,65$ \\
\hline Regency Pasaman Barat & $193.092 .373,45$ & $193.334 .659,07$ & $286.299 .604,83$ & $263.065 .434,07$ & $382.045 .523,79$ & $345.676 .029,99$ \\
\hline Regency Pesisir Selatan & $214.569 .785,78$ & $277.118 .287,02$ & $283.996 .331,00$ & $256.914 .361,73$ & $285.974 .782,24$ & $406.780 .290,79$ \\
\hline
\end{tabular}

expenditures includes direct expenditures from the government budget that can produce output in the form of fixed assets, where for the utilization of fixed assets produced can be used directly for public services, but there are also those used indirectly by the public or the community such as government office building. Based on the perspective of public policy, each annual budget for capital expenditure should be relatively larger because most of the capital expenditure is for public services.

The allocation of capital expenditures also sometimes experiences obstacles such as differences in the nominal prices that have been budgeted for capital expenditures that do not match / are not the same as the nominal real prices in the field, for example in the purchase of land, in addition, problems are often found in determining the specifications of the purchased fixed assets. such as the purchase of operational vehicles, or other assets. This is the cause of the unrealized capital expenditures properly, so that the allocation of capital expenditures is low (N. Sari et al., 2018). The following is a description of the capital expenditure value of Regency and City governments in West Sumatra from 2014 - 2019 in units of thousands of rupiah: 


\begin{tabular}{|c|c|c|c|c|c|c|}
\hline \multirow{2}{*}{ District / City } & \multicolumn{6}{|c|}{ Capital Expenditure } \\
\hline & 2014 & 2015 & 2016 & 2017 & 2018 & 2019 \\
\hline Regency Sijunjung & $144.579 .544,21$ & $167.695 .075,40$ & $243.956 .925,77$ & $189.756 .100,00$ & $209.583 .898,33$ & $212.104 .528,43$ \\
\hline Regency Solok & $175.926 .481,72$ & $179.309 .289,67$ & $205.316 .599,06$ & $204.616 .665,89$ & $189.207 .852,41$ & $214.435 .154,52$ \\
\hline Regency Solok Selatan & $183.842 .571,98$ & $215.458 .902,30$ & $233.649 .779,50$ & $230.734 .913,89$ & $238.322 .318,64$ & $158.753 .785,24$ \\
\hline Regency Tanah Datar City & $123.046 .707,00$ & $137.034 .861,00$ & $187.784 .872,00$ & $197.916 .991,00$ & $185.338 .702,00$ & $229.294 .175,00$ \\
\hline Bukittinggi City & $76.551 .550,64$ & $69.174 .912,58$ & $80.926 .569,09$ & $113.994 .191,85$ & $251.923 .630,00$ & $303.249 .283,52$ \\
\hline Padang City & $272.949 .994,00$ & $287.580 .511,20$ & $408.310 .076,09$ & $397.843 .408,96$ & $415.171 .576,57$ & $608.641 .732,92$ \\
\hline Padang Panjang City & $64.712 .665,45$ & $111.190 .408,00$ & $146.899 .922,00$ & $211.509 .246,01$ & $145.269 .249,00$ & $121.879 .206,00$ \\
\hline Pariaman City & $127.563 .060,43$ & $170.191 .189,29$ & $178.374 .780,97$ & $153.293 .150,20$ & $197.217 .061,86$ & $176.255 .655,20$ \\
\hline Payakumbuh City & $105.244 .228,49$ & $164.671 .738,97$ & $161.516 .312,33$ & $176.632 .639,12$ & $158.113 .415,34$ & $216.669 .763,01$ \\
\hline Sawahlunto City & $88.084 .914,07$ & $135.443 .678,88$ & $132.832 .856,00$ & $122.405 .870,00$ & $132.185 .554,00$ & $118.689 .542,00$ \\
\hline Solok City & $83.822 .290,47$ & $96.285 .406,80$ & $136.028 .384,72$ & $140.483 .121,18$ & $165.819 .540,45$ & $159.972 .370,69$ \\
\hline $\begin{array}{l}\text { Average } \\
\text { Expenditure }\end{array}$ & $153.579 .514,90$ & $181.179 .940,56$ & $221.868 .646,13$ & 226.235.340,95 & $235.244 .879,85$ & 264.558.770,91 \\
\hline Progress Percentage & & 17,97 & 22,46 & 1,97 & 3,98 & 12,46 \\
\hline
\end{tabular}

Source: BPS Book of Financial Statistics of Provincial and Regency/City Governments in West Sumatra 2014-2019, processed by the author

Based on the data in table 1 it can be seen that the average allocation growththe value of capital expenditures for district/city governments from 2014 to 2019 in units of thousands of rupiah has not allocated capital expenditures in the regional revenue budget of up to $30 \%$. In 2015 the realization of capital expenditure only reached $17.97 \%$ from 2014, in 2016 the percentage of capital expenditure realization increased to $22.46 \%$ from 2015, in 2017 the percentage of capital expenditure development decreased to $1.97 \%$ from 2015. 2016, and in 2018 the development of capital expenditure realization only reached $3.98 \%$ and increased in 2019 to reach $12.46 \%$.

The allocation of capital expenditures made is used for the provision of fixed assets that have a form with a value of benefits generated exceeding 12 months which are used in the relevant government activities. Economic growth as well as the amount of regional income will have an impact or influence on the welfare of the community, where this is a way to show the progress of a region. Furthermore, the welfare of the region concerned will be influenced by the amount of regional income, then the economic growth that occurs in the region and the progress of regional development, but not only that, special allocation funds and profit sharing funds included in the grouping of balancing funds also affect the progress of a region.

Fund The balance is obtained from the state budget revenue expenditure which is used for regions which are used to fund regional needs. Balancing funds are used to reduce the fiscal gap between the central government and regional governments, for economic development and improvement of regional progress and between regional governments (M. Syukri \& Didiharyono, 2018). The following can be seen a comparison of the average value of special allocation funds with the average value of capital expenditures for district and city governments in West Sumatra Province for the period 2014 - 2019 in units of thousands of rupiah: 
Table 2

Comparison of the Average Value of the Special Allocation Fund (DAK) and Capital Expenditures in the Regency and City Governments of West Sumatra Province for the 2014-2019 Fiscal Year (Thousand Rupiah)

\begin{tabular}{lrrrrrr}
\hline \multicolumn{1}{c}{ Year } & \multicolumn{1}{c}{$\mathbf{2 0 1 4}$} & $\mathbf{2 0 1 5}$ & $\mathbf{2 0 1 6}$ & $\mathbf{2 0 1 7}$ & $\mathbf{2 0 1 8}$ & $\mathbf{2 0 1 9}$ \\
\hline DAK average & $61.736 .348,13$ & $81.178 .778,00$ & $175.937 .136,74$ & $157.276 .039,41$ & $186.795 .675,42$ & $209.392 .366,68$ \\
\% Development & & 31,49 & 116,73 & $-10,61$ & 18,77 \\
average capital & & & & 12,10 \\
expenditure & $153.579 .514,90$ & $181.179 .940,56$ & $221.868 .646,13$ & $226.235 .340,95$ & $235.244 .879,85$ & $264.558 .770,91$ \\
\% Development & & 17,97 & 22,46 & 1,97 & 3,98 \\
\hline
\end{tabular}

Source: BPS Book of Financial Statistics of Provincial and Regency/City Governments in West Sumatra 2014-2019, processed by the author

Based on table 2 above, information is obtained that the average value of special allocation funds tends to increase and decrease the percentage of development which tends to be large every year compared to the percentage of average development of capital expenditures for the period 2014 to 2019, but From the percentage development of information obtained, it can be seen that the increase or decrease in the Special Allocation Fund does not have a significant effect on the magnitude of the increase and decrease in capital expenditures.

This situation is not in line with what it should be Juniawan \& Suryantini (2018) said that when the value of the Special Allocation Fund (DAK) that has been allocated by the central government is greater, the provision and procurement of services and facilities for local governments will experience a large increase as well through regional capital expenditures.

Fund The Special Allocation of sources of funding comes from state budget revenues which are submitted to certain regions with the aim of providing assistance in financing activities of a special nature which are regional affairs and adjusted to the scale of national priorities (Law No. 33 of 2004). The purpose of the Special Allocation Fund is to finance basic needs which are basically national program activities in the fields of education, health, environment, public works, clean water, fisheries, government, sanitation, marine, agriculture, forestry, family planning, trade and infrastructure. Village (Halim, 2014).

The next factor that has an impact on the use of capital expenditure in an area is profit sharing funds. Revenuesharing funds are a potential source of income for each region for regional income and can also be used as funds that become the basic capital for local governments to obtain funds that can be used as development funds and can also be used for regional expenditure funds, but the source of the funds is not comes from Regional Original Income (Aditya \& Maryono, 2018). According to law number 33 of 2004, the source of revenue-sharing funds comes from taxes obtained from the regional assets of the government concerned. Furthermore, in determining the profit-sharing funds obtained from natural resources in the local government, it is adjusted to the determination of the basis of calculation and the producing area. The distribution of profit-sharing funds is realized through revenues in the current fiscal year.

The following can be seen a comparison of the average value of profitsharing funds with the average value of district and city government capital expenditures in West Sumatra Province for the period 2014 - 2019 in units of thousands of rupiah: 
Table 3

Comparison of the Average Value of Profit Sharing Funds (DBH) and Capital xpenditures In the Regency and City Governments of West Sumatra Province Fiscal Year 2014 -2019 (Thousand Rupiah)

\begin{tabular}{|c|c|c|c|c|c|c|}
\hline Year & 2014 & 2015 & 2016 & 2017 & 2018 & 2019 \\
\hline average DBH & $22.502 .042,84$ & $18.466 .102,59$ & $19.752 .230,02$ & $18.446 .265,97$ & $20.439 .990,39$ & $20.212 .953,95$ \\
\hline \% Development & & $-17,94$ & 6,96 & $-6,61$ & 10,81 & $-1,11$ \\
\hline $\begin{array}{l}\text { average capital } \\
\text { expenditure }\end{array}$ & $153.579 .514,90$ & $181.179 .940,56$ & $221.868 .646,13$ & $226.235 .340,95$ & $235.244 .879,85$ & $\begin{array}{r}264.558 .770,9 \\
1\end{array}$ \\
\hline \% Development & & 17,97 & 22,46 & 1,97 & 3,98 & 12.46 \\
\hline
\end{tabular}

Source: BPS Book of Financial Statistics of Provincial and Regency/City Governments in West Sumatra 2014-2019, processed by the author

In 2018 the average profit-sharing percentage of development experienced a greater increase in spending by $10.81 \%$ with an average value of profit-sharing funds of Rp. 20,439,99.39 (thousand rupiah) compared to the percentage of development in the use of capital expenditure in 2018 of $3.98 \%$ with an average capital expenditure of $\mathrm{Rp}$ 235,244,879.85 (thousand rupiah). Furthermore, in 2019 the average profitsharing percentage of development experienced a large decline reaching $1.11 \%$ with an average value of profitsharing funds of Rp. 20,212,953.95 (thousand rupiah) compared to the percentage of development in the use of capital expenditures in 2019 which experienced an increase of $12.46 \%$ with an average capital expenditure of IDR $264,558,770$,

This situation contrary to conditions should Wandira (2013)said that regions that receive large revenuesharing funds will of course have large capital expenditures as well. This explains that the capital expenditure budgeted by a region is determined by the source of revenue sharing funds, so that one of the potential regional revenues is profit sharing funds because it can be used as one of the basic capital for regional development funds as well as to fulfill regional expenditures that are not comes from local revenue. How to determine the revenue sharing is done by giving a certain percentage, and the percentage is based on the district/city producing the revenue sharing funds, it is concluded that when there is an increase in the revenue sharing fund budget, it also has an impact on the allocation of capital expenditures,

The increase in the use of local government capital expenditure allocations can be influenced through the Remaining Budget Calculation (SiLPA). SiLPA is also able to influence the amount of budget allocation used to meet public expenditure needs in the form of capital expenditures(Rejeki et al., 2019). SiLPA is one of the markers that describes the efficiency of government spending, because SiLPA will be created if there is a surplus (difference) in the APBD and the formation of positive net financing, where revenue is greater than the component of financing expenditure (DGYA Sari et al., 2017).

SiLPA is the amount of cash as the remainder of the budget, on the other hand, the cash recorded in the final balance sheet is cash and cash equivalents owned by regional governments which are recorded due to budgetary or nonbudgetary activities. The SiLPA growth of a region can be used to assess budget performance. A high SiLPA value can cause both positive and negative effects for the region, the positive effect of SiLPA funds is in the form of reciprocity obtained by the Regional Government 
from SiLPA which is placed in banking deposits in the form of demand deposits or in the form of interest income, but must be included in other accounts from income the original area that is legalized at the same time can be used to add to the budget used for the following year (Arifah, Noor, \& Haryanto, 2019).

\section{Table 4}

The following can be seen the comparison of the average value of the remaining over budget calculations with the average value of capital expenditures in Regency and City regional governments in West Sumatra Province from 2014 - 2019 in units of thousands of rupiah:

\section{Comparison of the Average Value of FundsExcess of Budget Calculation and Capital Expenditures in the Regency and City Governments of West Sumatra Province Fiscal Year 2014 -2019 (Thousand Rupiah)

\begin{tabular}{lrrrrrr}
\hline \multicolumn{1}{c}{ Year } & $\mathbf{2 0 1 4}$ & $\mathbf{2 0 1 5}$ & $\mathbf{2 0 1 6}$ & $\mathbf{2 0 1 7}$ & $\mathbf{2 0 1 8}$ & $\mathbf{2 0 1 9}$ \\
\hline average SiLPA & $87.929 .904,53$ & $106.596 .995,96$ & $129.627 .564,53$ & $79.089 .755,43$ & $65.588 .601,20$ & $51.487 .381,12$ \\
\% Development & & 21,23 & 21,61 & $-38,99$ & $-17,07$ & $-21,50$ \\
average capital & & & & & & \\
expenditure & $153.579 .514,90$ & $181.179 .940,56$ & $221.868 .646,13$ & $226.235 .340,95$ & $235.244 .879,85$ & $264.558 .770,91$ \\
\% Development & & 17,97 & 22,46 & 1,97 & 3,98 & 12.46 \\
\hline
\end{tabular}

Source: BPS Book of Financial Statistics of Provincial and Regency/City Governments in West Sumatra 2014-2019, processed by the author

Based on table 4 , it is obtained information on the average remaining value of the calculation of the percentage of the development budget that tends to be stable, increasing from 2015-2016, but experiencing a decrease in 2017 to 2019. Based on the dataThis can be explained even though the percentage of development has changed, increasing or decreasing, on average, districts and cities in West Sumatra Province still have fundsthe remainder of the annual budget calculation, while for capital expenditure, it can be seen from thedevelopment percentage, the increase that occurs is not too large every year for the period 2015 to 2019. This can explain that an increase or decrease in remaining more calculationsthe budget does not have a significant impact on the magnitude of the increase and decrease in capital expenditures.

statecontrary to the conditions it should be Kusnandar \& Siswantoro (2012)concludes that the remaining excess of the previous year's budget calculations greatly influences the next year's expenditure allocation. Most of the remaining amount over the budget calculation will be donated to direct expenditures that are directly related to the needs of the community or what we call capital expenditures. The capital expenditure includes infrastructure expenditure, asset procurement and others, and also includes indirect expenditure, the use of which is not directly related to what is needed by the community.

Based on the explanation that has been described,So this research will focus on to examine the effect of special allocation funds, profit-sharing funds, and the remainder of the budget calculation on capital expenditures for district and city governments in the province of West Sumatra for the period 2014 - 2019. Through this study, researchers wanted to determine the effect of each variable partially or jointly - the same for capital expenditures.

\section{RESEARCH METHODOLOGY Types of research}

The type of research used is quantitative research.Sugiyono (2014) 
said quantitative research is used to examine a certain population/sample, then data is collected through instruments, where the data analyst is quantitative, the purpose of this analysis is to fulfill the proposed hypothesis. Furthermore, this research is used to test the hypothesis. In general, this study explains the phenomenon through the relationship between variables obtained from the facts (Indriantoro \& Bambang Supomo, 1999).

\section{Data Types and Sources}

The scale used is the ratio measurement scale. The ratio scale is used to correct the lack of a variable starting point on an interval scale, is a ratio scale that has an absolute zero point as opposed to an arbitrary one, with a significant measurement point (Ibrahim, 2003). Ratio scale is a scale that is intended to view the measurement results, which can be ordered, have a certain distance and can be compared.

The information used in this research is interpreted by using time series data analysis. Time series information is information collected from the same unit of observation in different periods of time. Next is time series information, namely data that is collected, recorded or observed in succession. Next to measure it using IBM SPSS Statistics 21 for Windows.

The information in this research has sources of information in the form of secondary information.(Sugiyono, 2014) said secondary information is information whose sources of information cannot directly share the necessary information with information gatherers. In this research, information is obtained from the website www.bps.go.id, Central BPS West Sumatra as well as http://sumbar.bps.go.id/publication. by referring to the data sources that have been obtained from the financial statements along with the realizations contained in the regional government for the period 2014-2019, which consists of special allocation funds, profit sharing funds, the remaining over budget calculations and capital expenditures.

\section{Population and Sample}

The object of this study are 19 regencies and cities in West Sumatra Province consisting of 12 regencies and 7 cities. Sugiyono (2014) The population is a generalization area consisting of objects/subjects that have certain qualities and characteristics set by the observer to be investigated and conclusions drawn. The population used in this research is 19 regencies and cities in West Sumatra Province, which consists of 12 regencies and 7 cities as well as reports on the realization of district and city revenue and expenditure budgets and APBD realizations found in local governments for the period 2014 2019.The sample is part of a number that has characteristics that are understood by the population (Sugiyono, 2014). The sampling procedure uses saturated sampling. Saturated sampling is the procedure for determining the sample if all members of the population are used as samples (Sugiyono, 2014). The sample of this study uses the entire population as an illustration, namely 19 regencies and cities in West Sumatra Province, which consists of 12 regencies and 7 cities.

\section{Data collection technique}

The method of collecting information used is documentation. For Sugiyono (2014) Documentation is a method used to obtain information and data in the form of books, archives, documents, written numbers and photos in the form of reports and explanations that can support research. The documentation used in this study includes the Financial Statistics report of the Provincial and District and City Governments of West Sumatra for the 2014-2019 period. 


\section{Data analysis technique}

\section{Classic assumption test}

\section{Normality Test}

In this test uji normality intended to study the regression model in this study has residuals that have been normally distributed or close to normal. A regression model is declared good if the residual value is normally distributed or close to normal (Kurniawan, 2014). Normality testing was carried out using the One Sample Kolmogrov - Smirnov Test. This statistical test tool is intended to see whether the data is normally distributed or not. Normally a data can be determined with the asymp sig (2tailed) value generated in the test that must be > alpha 0.05 (Ghozali, 2011).

2. Multicollinearity Test

The multicollinearity test is intended to understand whether the regression model in this research is an independent variable or the independent variable has no correlation or relationship. This regression model is declared good if the independent variable or the independent variable has no correlation. This testing method can be identified through the tolerance value and variance inflammatory factor (VIF). If the value of the variance inflammatory factor (VIF) is not more than 10 and the tolerance value is not less than 0.1 so that this model can be declared independent or free from multicollinearity, the VIF continues to be large, the lower the tolerance value (Kurniawan, 2014).

\section{Heteroscedasticity Test}

Heteroscedasticity test is a test that is intended to test whether a regression model has a comparison between the variance of one residual and the residual of another observation. The regression model is declared good if it already has criteria and requirements, namely if the data does not contain heteroscedasticity or there is an equation of variance or it is called homoscedasticity (Kurniawan, 2014). according to Ghozali (2011) Heteroscedasticity test method with glejser was carried out to regress the absolute value of the residual on the independent variable. If there is an independent variable that will statistically significantly affect the dependent variable, there will be an indication of the formation of heteroscedasticity. Where the significance probability value obtained is above the $5 \%$ confidence level. So this regression model can be concluded that there is no heteroscedasticity.

\section{Hypothesis testing}

\section{1.t test}

The t-test is intended to identify whether the independent variable or the independent variable partially (individually) has an effect on the dependent variable or the dependent variable. Assuming that is, if it is significant tcount that can be seen from the regression analysis displays a small value of $\alpha=5 \%$, meaning that the independent variable has an effect on the dependent variable. The criteria to ensure the decision of the hypothesis is to compare tcount with ttable, as follows:

1. If tcount < ttable at $>0.05$ then $\mathrm{H} 0$ is accepted and $\mathrm{Ha}$ is rejected.

If $\mathrm{H} 0$ is accepted, it means that the independent variable has no significant effect on the dependent variable.

2. If tcount $>$ ttable at $<0.05$ then $\mathrm{HO}$ is rejected and $\mathrm{Ha}$ is accepted.

If $\mathrm{HO}$ is rejected, it means that the independent variable has a significant effect on the dependent variable. 


\section{F Uji test}

The $\mathrm{F}$ test is intended to find out whether the independent variables together (simultaneously) have a significant effect or influence on the dependent variable. Testing with the $\mathrm{F}$ test is to compare Fcount with Ftable at $(\alpha)=5 \%(0.05)$. If the calculation results show:

1. Fcount $>$ Ftable, $<0.05$ then $\mathrm{H} 0$ is rejected and $\mathrm{Ha}$ is accepted.

This means that two or more independent variables simultaneously (together) have a significant effect on the dependent (bound) variable.

2. Fcount $<$ Ftable, $>0.05$ then $\mathrm{H} 0$ is accepted and $\mathrm{Ha}$ is rejected.

This means that two or more independent variables simultaneously (together) have no significant effect on the dependent variable.

\section{Determination Test}

The coefficient of determination is a factor that gets attention in the analysis. The coefficient of determination is intended to see how much the independent variable can explain the dependent variable. The writing is expressed as a percentage (\%). The coefficient of determination is divided into two parts, namely the usual coefficient of determination ( $\mathrm{R}$ Square) and the adjusted coefficient of determination (Adjusted R Square).

Nugroho (2005) say by using an adjusted R square or written Adjusted $\mathrm{R}$ square for linear regression to find out the coefficient of determination, to align it with the number of independent variables used, where if the independent variable is 1 (one) then $\mathrm{R}$ square is used and if it has exceeded 1 (one) using adjusted R square.

\section{Multiple Linear Regression Test}

Multiple linear regression analysis is used to predict the increase or decrease in the dependent variable, this occurs when two or more independent variables are manipulated by increasing or decreasing their value. The use of multiple linear regression analysis is intended to see the effect between the independent and dependent variables (Sugiyono, 2014). Where the formula used is as follows (Kurniawan, 2014):

$\mathrm{Y}=\mathrm{a}+\mathrm{b} 1$ it $\mathrm{X} 1$ it $+\mathrm{b} 2$ it $\mathrm{X} 2$ it $+\mathrm{b} 3$ it $\mathrm{X} 3 \mathrm{it}+\mathrm{e}$

Where:

Y : Capital expenditure

a : Constant

b1, b2, b3: Variable regression coefficient

$\mathrm{X} 1$ : Fund special allocation

$\mathrm{X} 2$ : Fund profit sharing

$\mathrm{X} 3$ : Excess of Budget Calculation

e : Confounding Variables

\section{RESULTS AND DISCUSSION}

\section{Classic assumption test}

\section{Uji Normality}

Normally a data can be determined with the asymp sig (2tailed) value generated in the test that must be > alpha 0.05 (Ghozali, 2011).

Table 5

Normality Test Results

One-Sample Kolmogorov-Smirnov Test

\begin{tabular}{|c|c|c|}
\hline & & $\begin{array}{c}\text { Standardized } \\
\text { Residual }\end{array}$ \\
\hline \multirow[t]{2}{*}{$\mathrm{N}$} & & 1144 \\
\hline & Mean & .0000000 \\
\hline Normal Parameters ${ }^{a, b}$ & $\begin{array}{l}\text { Std. } \\
\text { Deviation }\end{array}$ & 49939080.19 \\
\hline \multirow{3}{*}{$\begin{array}{l}\text { Most } \\
\text { Differences }\end{array}$} & Absolute & .107 \\
\hline & Positive & .107 \\
\hline & Negative & -.077 \\
\hline \multicolumn{2}{|l|}{ Kolmogorov-Smirnov $Z$} & 1.148 \\
\hline \multicolumn{2}{|l|}{ Asymp. Sig. (2-tailed) } & .144 \\
\hline \\
\hline & \multicolumn{2}{|c|}{$\begin{array}{l}\text { b. Calculated from data } \\
\text { Source. Secondary }\end{array}$} \\
\hline \multicolumn{3}{|c|}{$\begin{array}{l}\text { Source: Secondary Data Processing Results, } \\
2021\end{array}$} \\
\hline
\end{tabular}


From the table it can be seen that the Asym value. Sig (2-tailed) of 0.144. This shows that the significance value is greater than $0.05(0.144>0.05)$, so the residual value in this study is concluded to be normally distributed. So, overall it can be concluded that the data in this study are normally distributed.

\section{Multicollinearity Test}

In this analysis, the tolerance value and VIF value for each variable are obtained as follows:

Table 6

\begin{tabular}{|c|c|c|c|}
\hline \multirow{2}{*}{\multicolumn{2}{|c|}{ Model }} & \multicolumn{2}{|c|}{ Collinearity Statistics } \\
\hline & & Tolerance & VIF \\
\hline \multirow{4}{*}{1} & (Constant) & & \\
\hline & Special Allocation Fund (DAK) & ,923 & 1,084 \\
\hline & Revenue Sharing Fund (DBH) & 804 & 1,244 \\
\hline & $\begin{array}{l}\text { Remaining Budget Calculation } \\
\text { (SiLPA) }\end{array}$ & 823 & 1,215 \\
\hline
\end{tabular}

Source: Secondary Data Processing Results, 2021

From the results of the analysis, obtained three independent variables (independent) in this study the VIF value is not more than 10 and the tolerance is not less than 0.1 . This means that there is no multicollinearity between the independent variables. Thus, it can be concluded that the independent variables are in the form ofSpecial Allocation Funds (DAK), Profit Sharing Funds (DBH) and the remainder of the budget calculation (SiLPA) meets the requirements of the classical assumption of multicollinearity.

\section{Heteroscedasticity Test}

From the results of the heteroscedasticity test that was tried on this research, it was obtained as shown in Table 7 below:
Table 7

Heteroscedasticity Test Results

\begin{tabular}{|c|c|c|c|c|c|}
\hline \multirow{2}{*}{ Model } & \multicolumn{2}{|c|}{$\begin{array}{l}\text { Unstandarized } \\
\text { Coefficients }\end{array}$} & \multirow{2}{*}{$\begin{array}{c}\begin{array}{l}\text { Standardized } \\
\text { Coefficients }\end{array} \\
\text { Beta }\end{array}$} & \multirow{2}{*}{$\mathbf{t}$} & \multirow{2}{*}{ Sig. } \\
\hline & B & $\begin{array}{c}\text { Std. } \\
\text { Error }\end{array}$ & & & \\
\hline 1 (Constant) & $\begin{array}{l}23383849, \\
299\end{array}$ & 4.223 & & 2,718 &, 008 \\
\hline $\begin{array}{l}\text { Special } \\
\text { Allocation } \\
\text { Fund } \\
\text { (DAK) }\end{array}$ & ,067 & ,038 &, 171 & 1,783 & ,077 \\
\hline $\begin{array}{l}\text { Revenue } \\
\text { Sharing } \\
\text { Fund } \\
\text { (DBH) }\end{array}$ & ,429 & ,290 &, 152 & 1,480 &, 142 \\
\hline $\begin{array}{l}\text { Remaining } \\
\text { Budget } \\
\text { Calculation } \\
\text { (SiLPA) }\end{array}$ &,- 066 & ,063 &,- 105 & $-1,038$ &, 302 \\
\hline
\end{tabular}

Source: Secondary Data Processing Results, 2021

From the results of the analysis obtained three independent variables (independent) in the form ofSpecial Allocation Funds (DAK), Profit Sharing Funds (DBH) and the remainder of the budget calculation (SILPA) in this research the significance value is $>0.05$ until it is concluded that the regression model does not have heteroscedasticity as stated (Ghozali, 2011:143).

\section{Hypothesis Test Results t test}

The t-test is intended to identify whether the independent variable or the independent variable partially (individually) has an effect on the dependent variable and the dependent variable. The criteria for determining the correctness of the hypothesis decision is to compare $t_{\text {count }}$ with $t_{\text {table, }}$ as follows If $t_{\text {coun }} t>t_{\text {table }}$ at $<$ 0.05 then $\mathrm{H}_{0}$ is rejected and $\mathrm{Ha}$ is accepted. If $\mathrm{H}_{0}$ is rejected, it means that the independent variable has a significant effect on the dependent variable. At degrees of freedom $(\mathrm{df})=$ 
$\mathrm{nk}=114-4=110$, where $\mathrm{n}=$ number of samples, $\mathrm{k}=$ number of variables, the value of $\mathrm{t}$ table at the 0.05 significance level of confidence is 1.982. The results of data processing can be seen as follows:

Table 8

Partial Hypothesis Test Results (t Test)

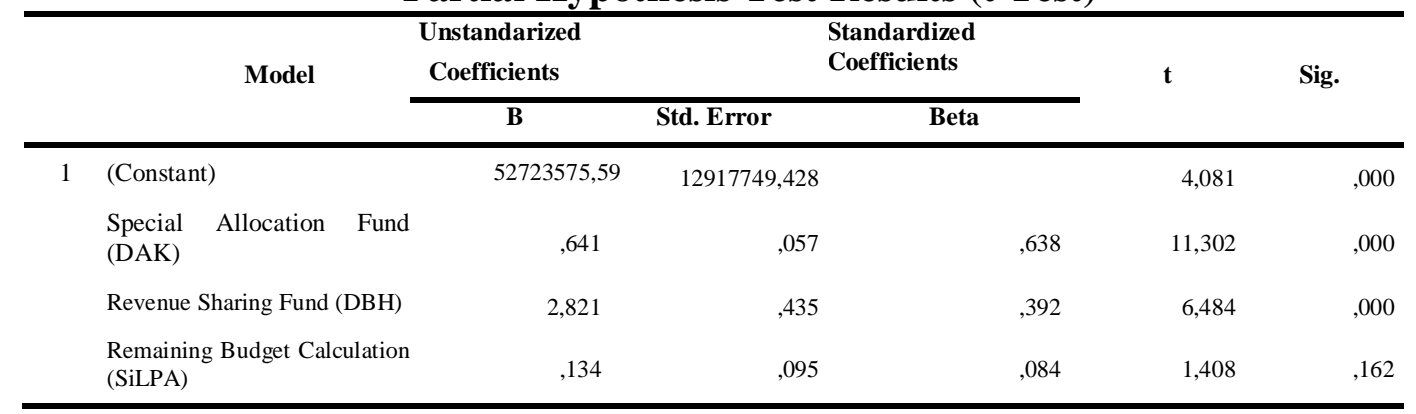

Source: Secondary Data Processing Results, 2021

\section{a. Influence Special Allocation Fund (DAK) for Capital Expenditure}

Based on table 8 can be shown the regression coefficient Special Allocation Fund (DAK) positive slope of 0.641 with $\mathrm{t}_{\text {count }}=11.302>$ $\mathrm{t}_{\text {table }}=1.982$ and a significance value of 0.000 ( $\mathrm{sig}<0.05)$. Based on the above analysis, it is concluded thatSpecial Allocation Fund (DAK) significant positive effect on capital expenditure in 19 districts and cities in West Sumatra Province so that the hypothesis is accepted.

b. Influence Revenue Sharing Fund (DBH) Against Capital Based on table 8, it can be explained that the regression coefficientRevenue Sharing Fund (DBH) positive slope of 2.821 with $\mathrm{t}_{\text {count }}=6.484>\mathrm{t}_{\text {table }}=1.982$ and $\mathrm{a}$ significance value of 0.000 ( $\mathrm{sig}<$ 0.05). Based on the above analysis it is concluded thatRevenue Sharing Fund (DBH) significant positive effect on capital expenditure in 19 districts and cities in West Sumatra Province so that the hypothesis is accepted.

\section{c. Influence Excess of Budget Calculation (SILPA) Against Capital Expenditure}

Based on table 8, it can be explained that the regression coefficientExcess of Budget Calculation (SiLPA) positive slope of 0.134 with $\mathrm{t}_{\text {count }}=1.408<\mathrm{t}_{\text {table }}=$ 1.982 and a significance value of 0.162 ( $\mathrm{sig}>0.05$ ). Based on the above analysis it is concluded that Excess of Budget Calculation (SiLPA) no significant effect on capital expenditure in 19 districts and cities in West Sumatra Province so that the hypothesis is rejected.

\section{f Uji test}

The $\mathrm{F}$ test is intended to see whether the independent variables together (simultaneously) have a significant effect or effect on the dependent variable. Testing with the $\mathrm{F}$ test is to compare $\mathrm{F}_{\text {count }}$ with $\mathrm{F}_{\text {table }}$ at $(\alpha)=5 \%(0.05)$. If the calculation results show $\mathrm{F}_{\text {count }}>\mathrm{F}_{\text {table }},<0.05$ then $\mathrm{H}_{0}$ is rejected and $\mathrm{Ha}$ is accepted. This means that two or more independent variables simultaneously (together) have a significant effect on the dependent variable. 
At degrees of freedom 1 (df1) = number of variables $-1=4-1=3$, and degrees of freedom $2(\mathrm{df} 2)=\mathrm{nk}=114-$ $4=110$, where $\mathrm{n}=$ number of samples,

Table 9

Simultaneous Hypothesis Test Results (Test F) $\mathrm{k}=$ number of variables, the value of $\mathrm{f}$ table in the 0.05 significance level of confidence is 2.687

ANOVA

\begin{tabular}{|c|c|c|c|c|c|c|}
\hline \multicolumn{2}{|c|}{ Model } & \multirow{2}{*}{$\frac{\text { Sum of Squares }}{588916721934958000,0}$} & \multirow{2}{*}{$\frac{\text { df }}{3}$} & \multirow{2}{*}{$\frac{\text { Mean Square }}{196305573978319300}$} & \multirow{2}{*}{$\frac{F}{76,624}$} & \multirow{2}{*}{$\frac{\text { Sig. }}{, 000^{\mathrm{b}}}$} \\
\hline 1 & Regression & & & & & \\
\hline & Residual & 281812025526948400,0 & 110 & 2561927504790440,000 & & \\
\hline & Total & 870728747461906000,0 & 113 & & & \\
\hline
\end{tabular}

a. Capital Expenditure

b. Excess Budget Calculation (SiLPA), Special Allocation Fund (DAK), Revenue Sharing Fund (DBH)

Source: Secondary Data Processing Results, 2021

Based on table 9 the value of the $\mathrm{F}_{\text {table }}$ at the 0.05 significance level of confidence is 2.687 , thus $\mathrm{F}_{\text {count }}=$ $76.624>\mathrm{F}$ table $=2.687$ with a significance level of 0.000 because the probability of significance is much smaller than sig < 0.05 , so it can be stated that Special Allocation Funds (DAK), Profit Sharing Funds (DBH) and the remainder of the budget calculation (SiLPA) together have a significant positive effect on capital expenditure in 19 districts and cities in West Sumatra Province.

\section{Determination Test}

The coefficient of determination is intended to determine how much the independent variable can explain the dependent variable. Nugroho (2005:51) say using an adjusted R square or written Adjusted $\mathrm{R}$ square for linear regression to see the coefficient of determination, in order to align with the number of independent variables used, where if the independent variable is 1 (one) to use $\mathrm{R}$ square and if it exceeds 1 (one) using adjusted $\mathrm{R}$ square. Based on the data estimation process that has been tried to do until a summary of the test results is obtained as shown in Table 10 below:

Table 10

Determination Test Results Model Summary

\begin{tabular}{llrrr}
$\begin{array}{l}\text { Mode } \\
\mathbf{l}\end{array}$ & $\mathbf{R}$ & R Square & $\begin{array}{c}\text { Adjusted R } \\
\text { Square }\end{array}$ & $\begin{array}{c}\text { Std. Error of } \\
\text { the Estimate }\end{array}$ \\
\hline 1 &, $822^{a}$ &, 676 &, 668 & 50615486,8 \\
\hline a. & Predictors : Excess Budget Calculation (SiLPA), Special Allocation
\end{tabular}

Predictors : Excess Budget Calculation (SiLPA), Special Allocatio Fund (DAK), Revenue Sharing Fund (DBH)

b. Dependent : Capital Expenditure

Source: Secondary Data Processing Results, 2021

Based on table 10 above, it can be explained that the adjusted $\mathrm{R}$ square value is 0.668 , this means $66.8 \%$ of capital expenditure in 19 regencies and cities in West Sumatra Province which can be described bySpecial Allocation Funds (DAK), Profit Sharing Funds (DBH) and the remainder of the budget calculation (SiLPA) while the remaining $33.2 \%$ is explained by other factors not examined in this study.

\section{Results Multiple Linear Regression Test}

From the results of data processing that has been tried to do, a summary of the test results is obtained as shown in table 11 below: 
Table 11

Multiple Linear Regression Analysis Results

\begin{tabular}{|c|c|c|c|c|c|c|}
\hline \multicolumn{7}{|c|}{ Unstandarized } \\
\hline & \multirow{2}{*}{ Model } & \multirow{2}{*}{$\begin{array}{l}\text { Unstandarized } \\
\text { Coefficients } \\
\text { B }\end{array}$} & & $\begin{array}{l}\text { dized } \\
\text { ents }\end{array}$ & \multirow{2}{*}{$\mathbf{t}$} & \multirow{2}{*}{ Sig. } \\
\hline & & & Std. Error & Beta & & \\
\hline \multirow[t]{4}{*}{1} & (Constant) & 52723575,59 & 12917749,428 & & 4,081 & ,000 \\
\hline & $\begin{array}{l}\text { Special Allocation } \quad \text { Fund } \\
\text { (DAK) }\end{array}$ & ,641 & ,057 & ,638 & 11,302 &, 000 \\
\hline & Revenue Sharing Fund (DBH) & 2,821 & ,435 & ,392 & 6,484 &, 000 \\
\hline & $\begin{array}{l}\text { Remaining Budget Calculation } \\
\text { (SiLPA) }\end{array}$ &, 134 & ,095 &, 084 & 1,408 & , 162 \\
\hline
\end{tabular}

Source: Secondary Data Processing Results, 2021

From the data processing that has been carried out, a summary of the test results is obtained as shown in the following multiple linear regression equation:

$$
\begin{gathered}
\mathrm{Y}=52723575.59+0.641 \mathrm{X} 1+2.821 \\
\mathrm{X} 2+0.134 \mathrm{X} 3+\mathrm{e}
\end{gathered}
$$

From these equations it can be concluded that:

a. The constant of 52723575.59 states that if the independent variable Special Allocation Funds (DAK), Profit Sharing Funds (DBH) and the remainder of the budget calculation (SILPA) is 0 or constant, then the capital expenditure in 19 districts and cities in West Sumatra Province is 52723575.59.

b. Regression coefficient Special allocation fund $(\mathrm{DAK})(\mathrm{X} 1)$ is 0.641 . The positive sign on this regression coefficient indicates that every increase inSpecial allocation fund (DAK) by 1 unit, it will result in an increase in capital expenditure in 19 regencies and cities in West Sumatra Province by 0.641 with the assumption that other independent variables are fixed.

c. Regression coefficient Profit sharing fund (DBH) (X2) is 2.821 . The positive sign on this regression coefficient indicates that every increase inProfit sharing fund (DBH) by 1 unit, it will result in an increase in capital expenditure in 19 regencies and cities in West Sumatra Province by 2.821 with the assumption that other independent variables are fixed.

d. Regression coefficient Excess of Budget Calculation (SiLPA) (X3) of 0.134 . The positive sign on this regression coefficient indicates that every increase inExcess of Budget Calculation (SiLPA) of units will result in an increase in capital expenditures in 19 regencies and cities in West Sumatra Province by 0.134 with the assumption that other independent variables are fixed.

\section{Discussion}

\section{The Effect of DAK on Capital Expenditure}

Based on table 11 it can be explained that the regression coefficient Special Allocation Fund (DAK) positive slope of 0.641 with $\mathrm{t}$ count $=11.302>\mathrm{t}$ table $=1.982$ and a significance value of 0.000 ( $\mathrm{sig}<0.05$ ). Based on the above analysis, it is concluded thatSpecial Allocation Fund (DAK) significant positive effect on capital expenditure in 19 districts and cities in West Sumatra Province so that the hypothesis is accepted. 
Thing This indicates that the size of DAK funds affects the size of funds for capital expenditures. Allocation of Special Allocation Funds provided by the center to local governments to increase regional needs in accordance with national policies and programs that are able to improve infrastructure, facilities and public facilities through capital expenditures.

Results from this study is in line with research conducted by(Juniawan \& Suryantini, 2018), (Abid et al., 2018), (Surakhman et al., 2019), (Suryana, 2018), and research (Wandira, 2013)which states that DAK has a significant positive effect on capital expenditures. This influence means that the size of DAK funds affects the size or size of funds for capital expenditures, which later on using DAK is expected to improve public services by realizing them in capital expenditures.

Based on the results of the study, it was found that DAK had a significant effect on capital expenditures. These results explain that district and city governments in the province of West Sumatra that receive large DAK will tend to have large capital expenditures, where on average the largest DAK value is in 2019 of Rp. 209,392,366.68 with regions that have a high value of special allocation funds, one of which is in the district of Padang Pariaman, which has an allocation of funds of Rp. $1,544,717,216.77$ or around $9.32 \%$ from 2014 - 2019. Meanwhile, the districts and cities in the province of West Sumatra that have the lowest allocation of special allocation funds are in the city of Padang Panjang which only has funds of Rp.306,140,095, - or only $1.85 \%$ from 2014 - 2019.

Regional revenues in the form of balancing funds (regional transfers) from the center require the regions to build and prosper their people through proportional and professional management of regional wealth and building sustainable infrastructure, one of which is budget allocation for the capital expenditure sector. District and city governments in the province of West Sumatra can use the DAK financial balance funds to provide services to the public which are realized through capital expenditures. The use of DAK is directed at investment activities for development, procurement, improvement, and repair of physical facilities and infrastructure with a long economic life, including the procurement of supporting physical facilities.

\section{The Effect of DBH on Capital Expenditure}

Based on table 11, it can be explained that the regression coefficient Revenue Sharing Fund (DBH) positive slope of 2.821 with $\mathrm{t}$ count $=6.484>\mathrm{t}$ table $=1.982$ and a significance value of 0.000 ( $\mathrm{sig}<0.05$ ). Based on the above analysis it is concluded thatRevenue Sharing Fund (DBH) significant positive effect on capital expenditure in 19 districts and cities in West Sumatra Province so that the hypothesis is accepted.

This indicates that the size of the DBH funds has an effect on the size of the funds for capital expenditures. The amount of $\mathrm{DBH}$ revenue for a region will certainly increase the APBD by identifying the components of $\mathrm{DBH}$, both tax DBH and SDA DBH, which make positive contributions and will increase regional capital expenditures.

Results This research is in line with research conducted by(Wandira, 2013), (Aditya \& Maryono, 2018), (Susanti \& Fahlevi, 2016), (Jikwa et al., 2015), and research (Kholidi et al., 2017)which states that DBH has a positive and significant effect on capital expenditures. This effect shows that if there is an increase in the transfer of Revenue Sharing Funds (DBH), it 
indicates an increase in the ability of the regions to make capital expenditures. So that the profit-sharing fund can be said as one of the funds that has the potential for basic capital for regional development.

Based on the results of these tests, it can be concluded that transfer funds through DBH received by districts and cities in the province of West Sumatra have a large and dominant influence on the increase in the allocation of capital expenditures, where on average the largest DBH value was in 2014 amounting to $\mathrm{Rp}$. 22,502,042.84 with areas that have a high value of profitsharing funds, one of which is in the city of Padang, which has an allocation of funds of Rp. 393,962,797.38 or around $17.31 \%$ from 2014 - 2019. Meanwhile, districts and cities in the province of West Sumatra that have the lowest allocation of revenue-sharing funds are found in the city of Padang Panjang which only has funds of Rp. 67,655,698.09 or only $2.97 \%$ from 2014 - 2019. This can provide an understanding that the higher exploitation of natural resources and revenue through taxes will encourage regional revenues to indirectly be able to have an effect on the amount of revenuesharing transfers and will increase capital expenditures, where DBH is a source of regional income that potential and is one of the basic capital of district and city governments in the province of West Sumatra in obtaining development funds and meeting regional expenditures that are not derived from DAK or SilPA. So that a vertical balance can be realized between the center and the regions by taking into account the potentials that exist in the region with a certain percentage based on the producing area.

\section{Effect of SiLPA on Capital Expenditure}

Based on table 11, it can be explained that the regression coefficientExcess of Budget Calculation
(SiLPA) positive slope of 0.134 with $t$ count $=1.408<\mathrm{t}$ table $=1.982$ and $\mathrm{a}$ significance value of 0.162 ( $\mathrm{sig}>0.05)$. Based on the above analysis it is concluded thatExcess of Budget Calculation (SiLPA) no significant effect on capital expenditure in 19 districts and cities in West Sumatra Province so that the hypothesis is rejected.

This finding shows that infrastructure development for public services is still being carried out even though it is not financed from the SiLPA of the 19 regencies and cities in West Sumatra Province. The fairly large SiLPA indicates that if the government is not right in budgeting regional expenditures, the excess budget should be used to finance capital expenditure activities related to public services.

In addition, the Excess Budget Financing is financing receipts used to cover the budget deficit if the realization of income is smaller than the actual expenditure, to fund the implementation of follow-up activities on direct expenditure expenses (goods and services expenditure, capital expenditure and personnel expenditure) and to fund other obligations up to and including: with the end of the fiscal year that has not been completed. So that not all of the excess Budget Financing is used for full Capital Expenditures because the Excess Budget Financing is also used for other activities that can help a region to cover the factors that cause a budget deficit.

The results of this study are in line with research conducted by (Fahrezi et al., 2020) and research (Talluta et al., 2018) which states that the excess of the Budget Calculation has a positive but not significant effect on capital expenditures. It can be said that not all of the SiLPA is used for capital expenditures because SiLPA is also used for other activities that can help the region to cover the factors that cause the budget deficit. 
Based on the research conducted, the Remaining Budget Calculation can be utilized by districts and cities in West Sumatra Province to maximize development programs in each district and city, where on average the largest SiLPA value was in 2016 of Rp. $129,627,564.53$ with the percentage of development of $21.61 \%$. One of the regions that has a high remaining budget calculation is the city of Padang, which has an allocation of Rp. 1,184,335,157.03 or around $11.98 \%$ from 2014 - 2019. Meanwhile, the districts and cities in the province of West Sumatra that have the lowest allocation of the remainder in the calculation of the budget are found in the Dharmasraya Regency which only has funds of Rp. 162,497,145.14 or only $1.64 \%$ from $2014-2019$. This SiLPA has an influence on the allocation of APBD for the next period, because SiLPA will be used to balance the budget by covering financing expenditures, although it is not very influential, but SiLPA still affects the development of capital expenditures in districts and cities in the province of West Sumatra, one of which is by focusing on development clean water infrastructure, construction of waterways, rehabilitation of damaged roads, and others, although in small numbers. The remaining funds obtained by the regional government are the remaining more than the calculation of the budget to finance development programs or public needs. This proves that although SiLPA is not the dominant factor affecting capital expenditure, it is in terms of planning and budgeting activities.

SiLPA describes an indicator that describes the efficiency of government spending. SiLPA is an indicator of efficiency, because SiLPA will be formed if there is a surplus in the APBD and positive net financing occurs, where the revenue component is greater than the financing expenditure component. The previous year's SiLPA, which was financing receipts, was used to cover the budget deficit if the actual income was less than the actual expenditure, as well as to fund the implementation of followup activities at the expense of capital expenditures and to fund other obligations such as debts and so on which had not been completed by the end of the fiscal year, so that the figure SiLPA is equal to zero.

\section{Effect of DAK, DBH and SiLPA together on Capital Expenditure}

Based on table 4.5 the value of the $\mathrm{F}$ table at the 0.05 significance level of confidence is 2.687 , thus $\mathrm{F}$ count $=$ $76.624>\mathrm{F}$ table $=2.687$ with a significance level of 0.000 because the probability of significance is much smaller than sig $<0.05$, it can be said that Special Allocation Funds (DAK), Profit Sharing Funds (DBH) and the remainder of the budget calculation (SiLPA) together have a significant positive effect on capital expenditures.

This indicates that the size of the special allocation funds, profit sharing funds, and the remaining budget calculations simultaneously affect the size of the funds for capital expenditures. The amount of revenue from special allocation funds, profit-sharing funds, and the remainder of the calculation of a regional budget if it increases will certainly increase the allocation of funds for capital expenditures, on the other hand if the special allocation funds, profitsharing funds, and the rest of the budget calculations experience a decrease, it will also have an impact. decrease in the allocation of funds for capital expenditures.

This research is in line with research conducted by(Mentayani \& Rusmanto, 2013) and research conducted by (N. Sari et al., 2018)which examines several factors that have an impact on capital expenditures, where together 
(simultaneously) all variables, namely special allocation funds, profit sharing funds and the rest of the budget calculations have an impact on the development of capital expenditures.

Based on this research, we can see that if there is an increase in special allocation funds, revenue-sharing funds and the rest of the budget calculations together, it will have an impact on increasing capital expenditures in 19 districts and cities in the province of West Sumatra. Vice versa if there is a decrease in funds from special allocation funds, profit sharing funds and the remaining excess of the budget calculation, it will also result in a decrease in the funds allocated for capital expenditures. The three independent variables were able to explain changes in capital expenditure in cities and districts in the province of West Sumatra by $66.8 \%$ while the remaining $33.2 \%$ was influenced by other variables not included in this study.

The partiality of the district and city governments in the province of West Sumatra towards improving public services by providing adequate facilities and infrastructure through the optimal allocation of funds for the capital expenditure budget will be optimal if balanced with regional financial capabilities. Efforts to increase regional fiscal capacity can be carried out by managing and increasing and optimizing revenues from balancing funds or transfer funds from the central government, namely in the form of special allocation funds and profit sharing funds and by optimally utilizing the remaining excess of the previous year's budget calculations to close the fiscal gap.

This indicates that the addition of special allocation funds, additional revenuesharing funds and an increase in the remaining budget over budget calculations from the basic assumptions affect changes in capital expenditures in the fields of education, health, and public works. In Pemdagri No.13/2006 it is emphasized that budgeting for expenditures must be supported by ensuring that sufficient funds are received.

\section{CONCLUSION}

Based on the results of a study on the effect of the Special Allocation Fund, Revenue Sharing Fund, and the Remaining Budget calculation, it shows that together they have a significant positive effect on Capital Expenditures in 19 districts and cities in West Sumatra Province, while the Special Allocation Fund, Revenue Sharing Fund in general Partial also has a significant positive effect on capital expenditures in 19 districts and cities in West Sumatra Province.

\section{ACKNOWLEDGMENTS}

Thanks to my supervisor and all support from STIE KBP Padang, who gave my chance to finish my article and bring them to journal. To BPS (Badan Pusat Statistik) many thanks also that gave my all data that $\mathrm{i}$ need to finish this research.

\section{REFERENCES}

Abid, M., Rahayu, S., \& Aminah, W. (2018). Pengaruh Pendapatan Asli Daerah, Dana Alokasi Umum,dan Dana Alokasi Khusus Terhadap Realisasi Anggaran Belanja Modal (Studi empiris pada Kabupaten/Kota di Provinsi Jawa Tengah Periode 2014-2015). E-Proceeding of Management, 5(1), 753-759.

Aditya, D. M. E., \& Maryono. (2018). Pengaruh Pendapatan Asli Daerah, Dana Alokasi Umum, Dana Alokasi Khusus, Dana Bagi Hasil Terhadap Belanja Modal (Studi Pada Provinsi/Wilayah Kalimantan dan Sulawesi). Prosiding SENDI_U 
2018, 33, 631-639.

Arifah, Noor, A., \& Haryanto. (2019). Analisis Pengaruh Sisa Anggaran, Pendapatan Asli Daerah dan Dana Perimbangan Terhadap Belanja Modal di Kabupaten/Kota Provinsi Jawa Tengah Tahun 2013 - 2017. Diponegoro Journal of Accounting, 8(2), $\quad 1-8$. https://doi.org/10.1017/CBO978110 7415324.004

Erlina, Rambe, O. S., \& Rasdianto. (2015). Akuntansi Keuangan Daerah Berbasis Akrual. Salemba Empat.

Fahrezi, F., Hasanah, N., \& Ulupui, I. G.

K. A. (2020). Pengaruh Pendapatan Asli Daerah, Dana Alokasi Umum, dan Sisa Lebih Pembiayaan Anggaran Terhadap Belanja Modal. 1(2), 141-157.

Ghozali, I. (2011). Analisis Multivariate Dengan Proses SPSS. Badan Penerbit Universitas Diponegoro.

Halim, A. (2008). Akuntansi Sektor Publik; Akuntansi Keuangan Daerah, (Edisi Ketiga) (Edisi keti). Salemba Empat.

Halim, A. (2014). Manajemen Keuangan Sektor Publik: Problematika Penerimaan dan Pengeluaran Pemerintah. Jakarta: Salemba Empat.

Halim, A., \& Kusufi, S. (2012). Akuntansi Sektor Publik; Teori, Konsep, dan Aplikasi. Salemba Empat.

Hidayat, F. M. (2013). Analisis Pengaruh Kinerja Keuangan Daerah Terhadap Alokasi Belanja Modal ( Studi pada Kabupaten dan Kota di Jawa Timur ). Jurnal Ilmiah Universitas Brawijaya.

Ibrahim, Y. (2003). Studi Kelayakan Bisnis. Rineka Cipta.

Indriantoro, N., \& Bambang Supomo. (1999). Metodologi Penelitian dan Bisnis. BPFE Yogyakarta.
Jensen, M. C., \& Meckling, W. H. (1976). Theory Of The FIRM: Managerial Behavior, Agency Costs and Ownership Structure. Journal of Financial Economics, 72(3), 305360.

https://doi.org/10.1177/0018726718 812602

Jikwa, E., Salle, A., \& Layuk, P. K. A. (2015). Pengaruh Pendapatan Transfer Dan SiLPA Terhadap Belanja Modal di Kabupaten Mamberamo Tengah. Keuda, 2(2), $1-17$.

https://doi.org/10.1111/j.13652621.2007.01616.x

Juniawan, M. A., \& Suryantini, N. P. S. (2018). Pengaruh PAD, DAU dan DAK Terhadap Belanja Modal Kota Dan Kabupaten Di Provinsi Bali. EJurnal Manajemen Universitas Unud, 7(3), 1255-1281. https://doi.org/10.24843/ejmunud.2 018.v7.i03.p05

Kholidi, A., Zamzami, H., \& Machpudin, A. (2017). Pengaruh Pendapatan Asli Daerah (PAD), Dana Alokasi Umum (DAU), Dana Alokasi Khusus (DAK) dan Dana Bagi Hasil (DBH) Terhadap Alokasi Belanja Modal (Studi Pada Pemerintah Kabupaten/Kota di Provinsi Jambi Tahun 2009 - 2014). Jurnal Akuntansi Dan Keuangan Unja, 2(1), 59-76.

Kurniawan, A. (2014). Metode Riset untuk Ekonomi dan Bisnis Teori, Konsep, dan Praktik Penelitian Bisnis (Dilengkapi Perhitungan Pengolahan Data dengan IBM SPSS 22,0). Alfabeta.

Kusnandar, \& Siswantoro, D. (2012). Pengaruh Dana Alokasi Umum, Pendapatan Asli Daerah, Sisa Lebih Pembiayaan Anggaran Dan Luas Wilayah Terhadap Belanja Modal. SNA XV Banjarmasin, 32, 1-20. 
Maulina, I., Nadirsyah, \& Darwanis. (2017). Pengaruh Sisa Lebih Anggaran Dan Pendapatan Asli Daerah Terhadap Perubahan Belanja Modal Studi pada Dinas Pekerjaan Umum Kabupaten/Kota Provinsi Aceh tahun 2013-2015. Jurnal Ekonomi Manajemen \& Bisnis -, 18(2), 191-196.

Mentayani, I., \& Rusmanto. (2013). Pengaruh Pendapatan Asli Daerah, Dana Alokasi Umum dan Sisa Lebih Pembiayaan Anggaran Terhadap Belanja Modal Pada Kota dan Kabupaten di Pulau Kalimantan. Jurnal Infestasi, 9(2), 91-102.

Nugroho, B. A. (2005). Strategi Jitu Memilih Metode Statistik Penelitian dengan SPSS. Andi.

Rejeki, S. D., Basri, H., \& Arfan, M. (2019). Pengaruh Pendapatan Asli Daerah, dan Alokasi Umum, Dana Otonomi Khusus, dan Sisa Lebih Penggunaan Anggaran Tehadap Belanja Modal Pada Fungsi Kesehatan. Jurnal Perspektif Ekonomi Darussalam, 5(2), 183198.

Saragih, J. P. (2003). Desentralisasi Fiskal dan Keuangan Daerah dalam Otonomi. Ghalia Indonesia.

Sari, D. G. Y. A., Kepramareni, P., \& Novitasari, N. L. G. (2017). Pengaruh Pertumbuhan Ekonomi, Pendapatan Asli Daerah, Dana Perimbangan dan Sisa Lebih Pembiayaan Anggaran Terhadap Alokasi Belanja Modal Kabupaten/Kota se- Bali. Jurnal KRISNA: Kumpulan Riset Akuntansi; $\quad 9(1), \quad$ 15-29. https://doi.org/10.22225.KR.9.1.32 5.15-29

Sari, N., Djuanda, G., \& Sarwani. (2018). Pengaruh Dana Perimbangan, Dana Sisa Lebih Perhitungan Anggaran (SiLPA) dan Pendapatan Asli Daerah Terhadap Belanja Modal
Dan Dampaknya Pada Pertumbuhan Ekonomi. Jurnal Riset Manajemen Dan Bisnis (JRMB) Fakultas Ekonomi UNIAT, 3(1), 91-100. https://doi.org/10.36226/jrmb.v3i1. 92

Sugiyono. (2014). Metode Penelitian Bisnis (Pendekatan Kuantitatif, Kualitatif dan $R \& D$ ). Alfabeta.

Surakhman, A., Djazuli, A., \& Choiriyah. (2019). Pengaruh Dana Alokasi Umum (DAU), Dana Alokasi Khusus (DAK) dan Pendapatan Asli Daerah (PAD) Terhadap Belanja Modal Pemerintah Kota Palembang. Jurnal Manajemen, Bisnis Dan Akuntansi, 7(2), 150-166.

Suryana. (2018). Pengaruh Pendapatan Asli Daerah (PAD), Dana Alokasi Umum (DAU), Dana Alokasi Khusus (DAK) Terhadap Belanja Modal. Jurnal Ilmu Manajemen \& Bisnis ISSN :2337-411X, 9(2), 6774.

Susanti, S., \& Fahlevi, H. (2016). Pengaruh Pendapatan Asli Daerah, Dana Alokasi Umum, dan Dana Bagi Hasil Terhadap Belanja Modal (Studi Pada Kabupaten/Kota di Wilayah Aceh). Jurnal Ilmiah Mahasiswa Ekonomi Akuntansi (JIMEKA), 1(1), 183-191.

Syukri, M., \& Didiharyono. (2018). Pengaruh PAD, Dana Perimbangan dan PMA Terhadap Tingkat Kemajuan Daerah Kabupaten dan Kota di Provinsi Sulawesi Selatan. Masagena, 13(1), 525-534. https://doi.org/10.1017/CBO978110 7415324.004

Syukri, Muhammad, \& Hinaya, $H$. (2019). Pengaruh Pertumbuhan Ekonomi, Pendapatan Asli Daerah, Dana Alokasi Umum Dan Dana Alokasi Khusus Terhadap Anggaran Belanja Modal Kabupaten \& Kota Provinsi Sulawesi Selatan. JEMMA | 
Journal of Economic, Management and Accounting, 2(2), 30-37. https://doi.org/10.35914/jemma.v2i 2.245

Talluta, D. L. T., Lambelanova, R., \& Wargadinata, E. (2018). Pengaruh Pendapatan Asli Daerah, Dana Perimbangan, dan SILPA Terhadap Belanja Modal dan Dampaknya Kepada Pertumbuhan Ekonomi Pemerintah Daerah Kota Kupang Provinsi Nusa Tenggara Timur. Angewandte Chemie International Edition, 6(11), 951-952., 12(3), 351-376.

https://doi.org/10.1016/j.phrs.2020. 104743\%0Ahttps://doi.org/10.1057/ s41267-019-00222-y

Wandira, A. G. (2013). Pengaruh PAD, DAU, DAK, dan DBH Terhadap Pengalokasian Belanja Modal. Accounting Analysis Journal, 2(1), 44-51.

https://doi.org/10.15294/aaj.v2i1.11 58

Peraturan Menteri Keuangan (PMK) Nomor 91/PMK.06/2007 tentang Bagan Akun Standar (BAS).

Peraturan Pemerintah Republik Indonesia Nomor 55 Tahun 2005 tentang Dana Perimbangan.

Undang - Undang Nomor 33 Tahun 2004 tentang Perimbangan Keuangan antara Pemerintah Pusat dan Pemerintahan Daerah

Undang-Undang Republik Indonesia. Nomor 4 Tahun 2012 Tentang Anggaran Pendapatan dan Belanja Negara

Statistik Keuangan Pemerintah Daerah Provinsi dan KABUPATEN_KotA seSumatera Barat 2014

Statistik Keuangan Pemerintah Daerah Provinsi dan KABUPATEN_KoTA seSumatera Barat 2015 - 2016

Statistik Keuangan Pemerintah Daerah Provinsi dan KABUPATEN_KoTA seSumatera Barat 2016 - 2017
Statistik Keuangan Pemerintah Daerah Provinsi dan KABUPATEN_KotA seSumatera Barat $2017-2018$

Statistik Keuangan Pemerintah Daerah Provinsi dan KABUPATEN_KotA seSumatera Barat 2018 - 2019 